may have been the prototype of the Silurian Nodons. What is the orthography of Lydney? October 5

\section{Do Bacteria or their Germs exist in the Organs of Living Healthy Animals?}

IN the August number of the Fournal fiir praktische Chemie, Messrs. Nencki and Giacosa assert that bacteria and their germs exist in the organs of healthy living animals, in contradiction of Messrs. Chiene and Ewart, who took the negative side of this question in the Fournal of Anatomy and Physioiogy for April, 1878. I give the chief parts and points of Nencki and Giacosa's refutation.

"Dr. Burdon Saunderson repeated Tiegel's experiments. The organ just taken from a newly-killed animal was immediately plunged into paraffin heated to $110^{\circ}$. As soon as the mass cooled the surface was covered with Venetian turpentine, so as to protect the specimen from infection from without by the cracking of the paraffin. Burdon Saunderson aunounces that when two days after, the organ at the bottom of the vessel was taken out, it was in a clotted and rather cooked condition on the outside in consequence of the heat. But the centre contained numbers of bacteria in the various stages of their existence. . . The last-named authors (Chiene and Ewart) worked upon the conclusion that in the time between extracting the organ and plunging it into the paraffin, bacteria germs from the air fall unon it, thus causing the subsequent decomposition. This was to be guarded against by an antiseptic method. Their procedure, therefore, was as follows:-Under a continuous spray of a solution of carbolic acid, a newly killed rabbit's abdomen was opened, and the liver, spleen, kidneys, and pancreas extracted. The liver was cut into several pieces; some pieces were wrapped in gauze, soaked in a solution of carbolic acid. Others were wrapped in unprepared gauze; while others were put into jars which were raised to a great heat, and then closed up with wool, gauze, or glass covers. The same was done with the other organs. After three days, the specimens were examined, and no bacteria were found in those which had been wrapped in antiseptic gauze. . . Mesirs. Chiene and Ewart therefore conclude that if the oryans are treated antiseptically after death, no bacteria or germs of them will be found; and that hence no germs of bacteria exist in the living, healthy organs. ..." Messrs. Nencki and Giacosa thus describe an experiment which they made, in order to prove the contrary. There was a vessel containing mercury; a large glass test-tube, filled with mercury, closed with a slip of glass, and inverted in the vessel. The latter was then heated till the tube was onethird filled with mercury vapour, which must have destroyed any bacteria which could by any possibility bave remained in it. The vessel was allowed to cool; the quicksilver in the tube condensed again; and when the mercury in the outer jar was at $120^{\circ}$, it was covered with a 5 per cent. solution of carbolic acid." Some internal organ (liver, heart, kidneys, or spleen) was then taken from a rabbit that had just been killed, and with a pair of tw'eezers was brought under the mouth of the tube, up which it ascended when let go. The apparatus was then kept at a temperature of $40^{\circ}$ for several days. The results of all experiments corducted in this way were favourable to the admission that bacteria exist in the organs of living healthy animals. Already in twenty-four hours all the organs, when examined, gave out an inteasely foul odour, and showed countless split fungi in different forms. ... The beginning of putrefaction is shown by the pressing down of the mercury in the tube by the generation of gases. . . . All the vessels and instruments we employed ware lifted out, immediately before use, from a carbolic acid solution. ... Why, then, did putrefaction not set in in Messrs. Chiene and Ewart's experiments? That neither a spray of, nor transient immersion in, carbolic acid will hill the gerns in the tisstes, is proved by our experiment, in which the organ is passed through the solution into the mercury and up the tube. But it is a different thing when the organ is for a long time in contact with material (the antiseptic gauze) previously soaked in the solution of carbolic acid." This, Nencki and Giacosa prove by experiment. And it seems to be natural that while a brief iunersion in the antiseptic solution must be amply sufficient to destroy any bacteria which might have lodged upon the organ in its transit through the atmosphere, prolonged contact with the solution must cause the inmost parts of the specimen to be permeated by the destroying poison, thus rendering the results of the subsequent examination null and void in their bearing on the question. In conclusion, Messrs. Nenchi and Giacosa maintain that pathologists must accept the fact that the germs of bacteria exist in the organs of living healthy animals, and advise them to consider this in their studies of infectious diseases, as the existence of ordinary decomposition bacteria in the tissues indicates that it may be different forms of them which are the causes of various contagious maladies.

E. BURKE, jun.

\section{Subject-Indexes to Transactions of Learned Bodies}

MR. GaRnetT, in his paper printed in NATURE, vol, xx. p. 554, proposes to make the Index to Scientific Periodicals by cutting up two copies of the Royal Society's Catalogue and using this as the "copy" for the Index; but the thought has struck me that if the "copy" of the Royal Society's Catalogue is still in existence there is the material ready to hand for commencing work at once. I believe the Index might be done this way by any one who had access to the chief periodicals; but the title of a paper is often so very deceptive that without frequent reference to the papers themselves I am afraid we should get even worse mistakes than the one mentioned by Mr. Garnett. Now that the last volume of the Catalogue is out it is sincerely to be hoped that the Council of the Royal Society will take this "Subject-Index" into consideration.

October Io

JAS. B. BAILEY

\section{Change of Colour in Frogs}

IT is certainly a common opinion in this part of the country that when frogs become of a bright yellow colour fine weather may be expected. The brightness of colour can scarcely be due to the presence of sunlight, for frogs of a bright yellow may frequently be found in cellars, wells, and other dark places. Throughout the past summer and up to the present time, I have noticed that the frogs in this neighbourhood have been of an extraordinarily brilliant yellow tint. Again and again have I heard the country people, working in the hay or corn fields, under the unbroken canopy of cloud, remark-"We must be going to have fine weather now, for look at the colour of the frogs." These forecasts proved the reverse of successful.

Asbby Parva, Lutterworth, October 10 W. Clement Ley

AT the commencement of "the ruins" (say, beginning of Tune), in the island of Bombay, after the first showers, when a Iittle water lodges in the depressions of the old-quarry tanks, the frogs issue from the crevices of the trap-rock to spawn, when the $m a^{7} e s$ (some of which are 18 inches in length from tip of toe to end of digit) assume a bright mustarcl-yellow colour, while the femalez remain brown as ustul; and this change of colour takes place so rapidly, and the frogs are so numerous, that, with the falling of the showers, the bottom of the quarry becomes suddenly yellow. I never saw a frog so coloured at any other time and I witnessed the fact above mentioned for at least two successive seasons in the same old quacry. H. J. CARTER

Devon, October I3

\section{Intellec: in Brutes}

The case of the Norwegian dog, Nero, mentioned by Mr. Horsfall in NatURE, vol. xx. p. 505 , is certainly an admirable example of abstract reasoning. Here the dog thought as any man would have thought how, where, and when to catch the vailway train suited to his purpose. It lias reminded me that, when I was in Malta a few years ago, a fine Newfoundland dog (if I remember correctly) used to accompany Miss Hallett in her ride from Sliema to Valetta on a visit to her grandfather in Strada Forni. The ride is about four miles round the head of the harbour. On one occasion she observed that the dog had ceased to follow her, and concluded that, owing to the heat or some other cause, it had returned home. Her surprise was considerable on arriving in Strada Forni, for there she found the dog waing for her at her grandfather's cloor. The explanation is, as was subsequently discorered by a frequent repetition of the same thunghtful dodge: the dog had gone to the ferry, waited there until passengers stepped into the boat, got in himself, was ferried across the harbour, and in this way was saved a long and, it may be, a hot and a dusty run. So far as I can remember, the animal had no previous experience of this short 